を完全に取り除くことはできなかった。しかし，通常臨 床の場で使用する screen/film (グリーン系，ブルー系) での測定においては，鉛マスクを使用してもしなくても MTF 值に明らかな差はなく，チャート自体からの散乱 線が存在はするが測定值に有意な影響はでないものであ った.

\section{3 背後散乱線の影響}

\section{3 .1 目 的}

MTF 測定の際，床，壁，鉛材等フィルム位置付近の物 質からの散乱線が，測定値に影響を及ぽすことが考えら れる、ここでは，フィルム背後のコンクリート床，鉛板 からの散乱線の影響を検討した。

\section{3 .2 実験方法}

チャートは，Fig.4-1 (a)と(b)に示した配置にて撮影を 行なった。高さ $30 \mathrm{~cm}$ の支持台 $(1 \mathrm{~cm}$ 厚発泡スチロール 製）の上にチャートとフィルムを設置した場合，この支 持台の上に $1.5 \mathrm{~mm}$ 厚鉛板をのせその上に設置した場合 および直接コンクリート床にチャートとフィルムを設置 した場合で実験を行なった。チャートの上には，チャー 卜自体加らの散乱線の影響を考虑して, $1.5 \mathrm{~mm}$ 厚, 幅 4 mm の鉛マスクを置き, none screen/片面乳剂 film(Fuji $\mathrm{MI}-\mathrm{NH}$ ）を使用して，管電圧 $60 \mathrm{kV}$ で撮影した。他は， 1 の系と同様とした。また, screen/film（グリーン系 Lanex-Fine/TMG system, ブルー系 B3/RX system) を使用した場合についても検討した。

\section{3 .3 結果と考察}

Fig. 4-6に, none screen/片面乳剂 film の SWRF を 示す、フィルムの背後に鉛板：または，コンクリート床 がある場合では，背後散乱線の影響のない場合と比較し て，2〜3\%低いほ㴗同一の值となった. 背後散乱線の 影響は周波数領域で異なり，正規化周波数領域以外でコ

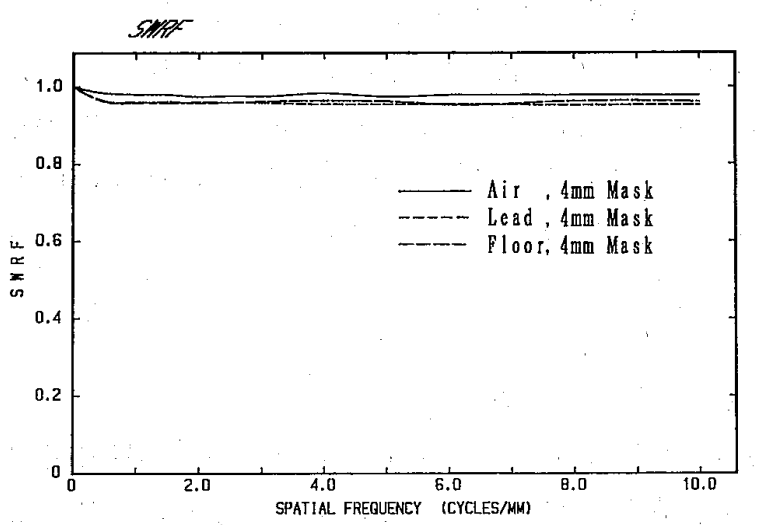

Fig. 4-6 背後散乱物質の有りと無しでの SWRF (None Screen) の比較

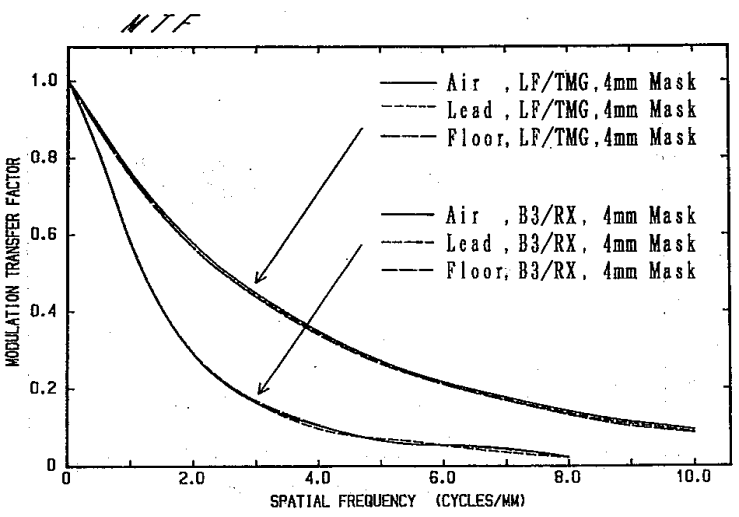

Fig. 4-7 背後散乱物質の有りと無しでの MTF (S/F-system：グリーン系，ブルー系) の比較

ントラストの低下が見られた。これにより SWRF の低 下を引き起こしている，今回は，この原因の確認はして いない.

Fig. 4-7 に, Lanex-Fine/TMG, B3/RX での MTF 測定結果を示す。グリーン系，ブルー系いずれの場合に おいても，背後散乱線の有無で MTF 值に差は見られな かった. 4.2.3と同樣の理由と考える。また，鉛板からは 散乱線に加え， L特性 X線 $(10.5 \mathrm{keV})$ の発生が諗めら れたが（モンテカルロシミュレーションによる解析に て), screen/film 系での MTF 值に影響は認められなか った.コンクリート床からの散乱エネルギー等は確認し ていないが，いずれにしても背後散乱線の゙ェルギー特 性により影響の程度は左右されるものと考える。

\section{3 .4 ま と め}

背後散乱線の影響は, none screen では MTF 值の低 下傾向で確認できたが, screen/film（グリーン系，ブル 一系)では鉛板，コンクリート床いずれの場合も MTF 测 定値の差として確認できなかった。しかし，背後物質の 材質が異なった場合, 散乱線のエネルギー特性が異なり 測定值に影響してくる可能性も十分考えられる。これら より，実験に際してはフィルム位置付近に散乱線の発生 源となる物質を置かないことを第一とし，やむを得ない 場合は散乱線を防ぐ目的で鉛板を使用することで測定精 度を確保できるものと考える。

（安城更生病院 澤田道人）

\section{第 5 章 マイクロデンシトメトリーに起}

\section{因する MTF の誤差の検討}

\section{1 はじめに}

一般に，X線写真の物理的な画質評価は，注意樑く作 成したサンプルフィルムの写真濃度を，マイクロデンシ 
トメータで測定し解析するという手順で行われている。 そして, 測定值の正確さを知るためには，解析方法や測 定機器の特徴を熟知寸る必要があることはいうまでもな W.

ここでは，矩形波チャート法による MTF 測定におい て，濃度測定に用いるマイクロデンシトメータに依存す る問題点のうち, 対物レンズの焦点の影響, アパーチュ アサイズの違いによる影響，チャート像サンプルの傾き による影響, サンプルステージの移動速度の影響につい て検討を行う.

\section{2 使用器具および機器}

この実験に使用した器具と機器.

センシトメータは Panorex dental X-ray machine （PARO 社）を用いた強度スケールX線センシトメータ (距離法)で，自家製である。チャート撮影のX線発生装 置はKXO-15(東芝), X線管はDRX-1603B (Focal spot size : $1.0 \mathrm{~mm} \times 1.0 \mathrm{~mm})$ である.

矩形波チャートは Kyoko type $1(0.5 \mathrm{mmPb}, 0.5$ cycles $/ \mathrm{mm} \sim 10$ cycles $/ \mathrm{mm})$, 増感紙/フイルムは Lanex Regular (KODAK)/TMG (KODAK) を用い た. マイクロデンシトメータは PDM-5 typeB(Konica) を使用した。

\section{3 実 験}

実験は次の 4 項目について行った。

1）マイクロデンシトメータの対物レンズの焦点位置 の MTF 值への影響

マイクロデンシトメータの対物レンズの焦点深度は, 両面のX線フィルム乳刜面に対してピントを同時に合わ せられるほど深くない.そこで，対物レンズのピントを サンプルフィルムの前面乳剂, 支持体, 後面乳剂にそれ ぞれ合わせた場合と，オフフォーカスの場合について MTF 值を測定し比較検討を行った。

2）アパーチュアサイズの MTF 值への影響

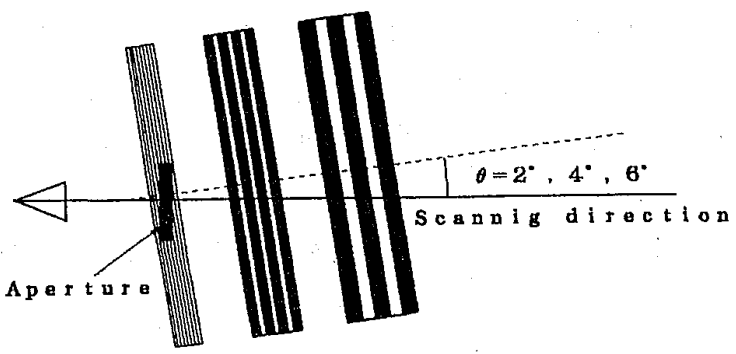

Fig. 5-1 This figure shows the scanning direction for the experiment of the effect of the variation in chart image inclination.
アパーチュアの高さ $0.2 \mathrm{~mm}, 0.5 \mathrm{~mm}, 0.8 \mathrm{~mm}$ と幅 $0.01 \mathrm{~mm}, 0.02 \mathrm{~mm}, 0.03 \mathrm{~mm}$ を組み合わせて MTF を 測定しその差を調べた。

3）チャート像サンプルの傾きによる MTF 值への影 響

チャート像をマイクロデンシトメータのステージに乗 せるときに気をつけなければならないことは，矩形波チ ヤート像の細線の長さ方向とアパーチュアの高さ方向と が正しく平行になるように整合することである：そこで， Fig.5-1のようにチャート像をアパーチュアと平行な状 態から $2^{\circ}, 4^{\circ}, 8^{\circ}$ と角度をつけた場合に MTF 值がどの程 度変化するのかを調べた。

4）マイクロデンシトメータのステージ移動速度の MTF 測定への影響

サンプルフィルムをサンプリングをする際に，マイク ロデンシトメータのステージを動かす速度はA/Dコン バータにおけるサンズリング周波数やアパーチュアの幅 と関連させて決められる。

濃度測定は，画像解析の過程の中でも非常に時間のか かる部分である.したがって, MTF 測定值に影響がない 範团でステージ移動を速くしてサンプリング周波数を上 げれば迅速な測定を行うことが可能になる。そこで，ス テージ速度を $0.1 \mathrm{~mm} / \mathrm{sec}, 0.25 \mathrm{~mm} / \mathrm{sec}, 0.5 \mathrm{~mm} / \mathrm{sec}$ と変化させて MTF を測定し，その值の変化を調べた。

\section{4 結 果}

結果を Fig. 5-2〜Fig. 5-7 に示卞。比較の基準となる MTF 測定時のマイクロデンシトメータの使用条件は次 のとおりである. 対物レンズの焦点位置は前面乳剂に合 わせる.アパーチュアサイズは，幅 $0.01 \mathrm{~mm}$ ，高さ 0.8 $\mathrm{mm}$ である.チャート像細線の長さ方向とアパーチュア

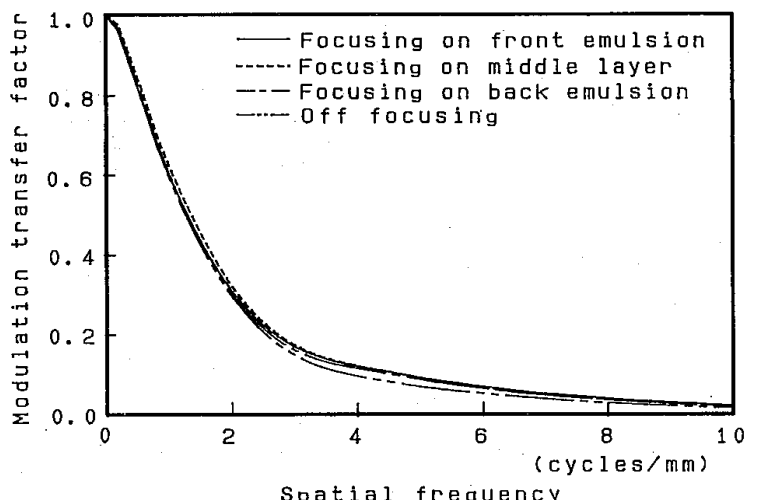

Fig. 5-2 The MTFs are measured with different burning points. These points are front emulsion, middle layer, back emulsion, and off focus. 
の高さ方向は平行にする. ステージ移動速度は, 0.1 $\mathrm{mm} / \mathrm{sec}$ とし $10 \mathrm{~Hz}$ でサンプリングする.

Fig. 5-2 に示すようにピントを前面乳剂, 支持体, 後面 乳剤に合わせた場合の MTF は，0〜10 cycles $/ \mathrm{mm}$ に

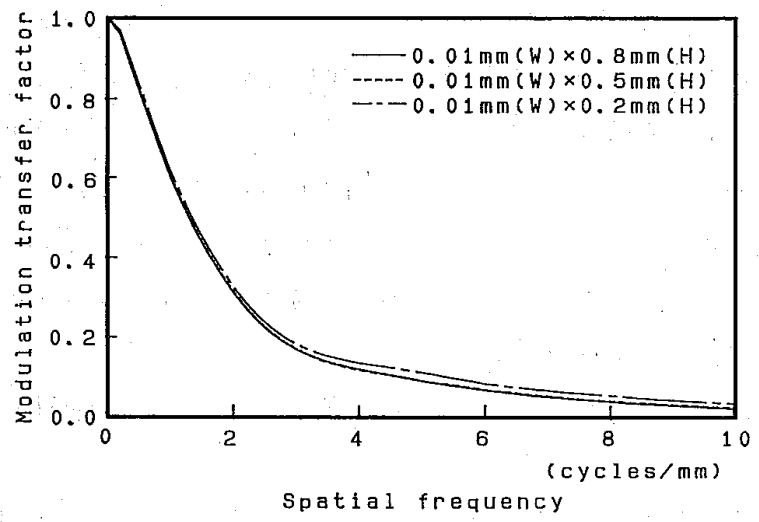

Fig. 5-3 MTFs are measured with $0.01 \mathrm{~mm}$ aperture width of microdensitometer. Aperture height is changed as $0.8 \mathrm{~mm}$, $0.5 \mathrm{~mm}$ and $0.2 \mathrm{~mm}$.

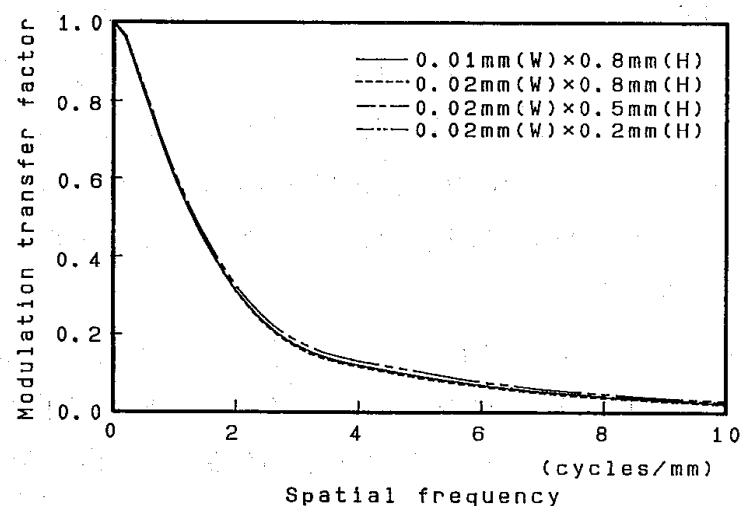

Fig. 5-4 Aperture height is changed as $0.8 \mathrm{~mm}$, $0.5 \mathrm{~mm}$ and $0.2 \mathrm{~mm}$. Aperture width is fixed at $0.02 \mathrm{~mm}$.

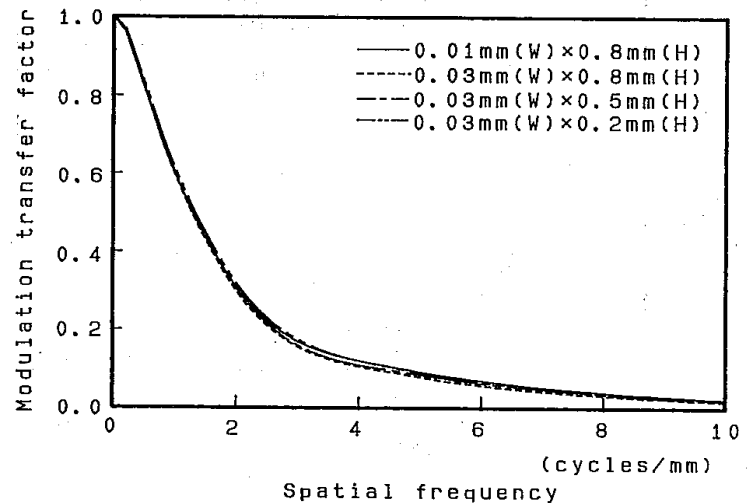

Fig. 5-5 Aperture height is changed as $0.8 \mathrm{~mm}$, $0.5 \mathrm{~mm}$ and $0.2 \mathrm{~mm}$. Aperture width is fixed at $0.03 \mathrm{~mm}$.

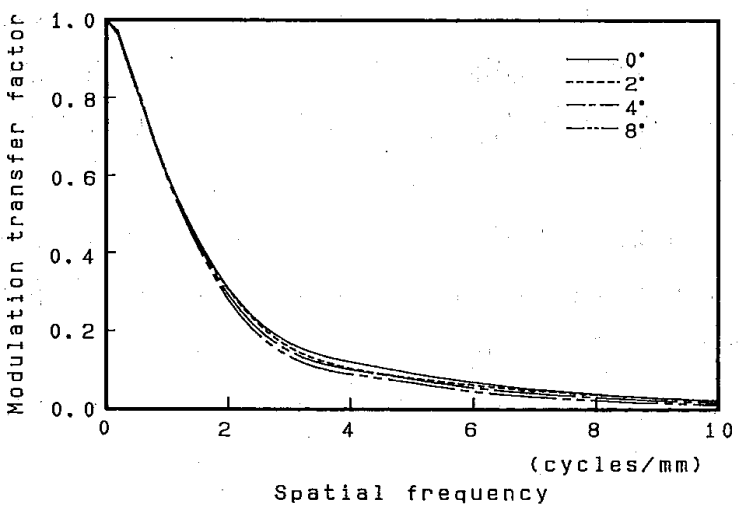

Fig. 5-6 The angle between chart image and scanning direction are $0^{\circ}, 2^{\circ}, 4^{\circ}$ and $8^{\circ}$.

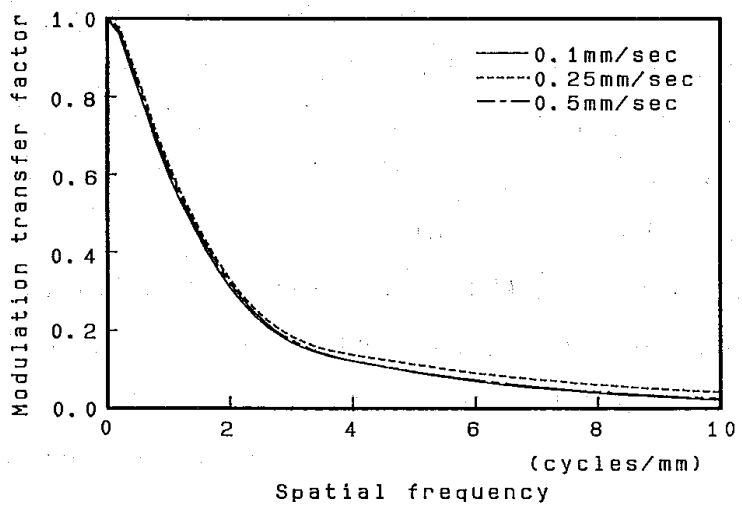

Fig. 5-7 Stage speed of the microdensitometer is changed as the parameter of the MTF's. They are $0.1 \mathrm{~mm} / \mathrm{sec}, 0.25$ $\mathrm{mm} / \mathrm{sec}$, and $0.5 \mathrm{~mm} / \mathrm{sec}$.

わたって大きな差は認められなかった．オフフォーカス の場合，全空間周波数領域に渡り MTF 值は低い值を示 した.

Fig. 5-3〜Fig. 5-5 はアパーチュアの幅をそれぞれ $0.01 \mathrm{~mm}, 0.02 \mathrm{~mm}, 0.03 \mathrm{~mm}$ にして高さを変えた場合 の MTF 測定結果である.アパーチュアの幅が $0.01 \mathrm{~mm}$ と0.02 mm の場合, 高さ $0.8 \mathrm{~mm}, 0.5 \mathrm{~mm}$ では MTF 值 にほとんど変化が見られなかったが, 高さ0.2 mm の場 合に MTF 值が高い值を示した。幅 $0.03 \mathrm{~mm}$ の場合は， アパーチュア高さに関係なく MTF 值は小さくなった。

Fig. 5-6 はチャート像サンプルの傾きに関しての実験 結果である。サンプルの角度を $2^{\circ}, 4^{\circ}, 8^{\circ}$ と変えたが，角 度が大きくなるにしたがって MTF 值の低下がみられた。

Fig. 5-7 はステージ移動速度を変えて測定した MTF である.ステージ速度 $0.1 \mathrm{~mm} / \mathrm{sec} と 0.5 \mathrm{~mm} / \mathrm{sec} の$ MTF 值は大きな差が見られなかったが， $0.25 \mathrm{~mm} / \mathrm{sec}$ の MTF 值は高くなった。

5.5 考 察 
Fig. 5-2 においてオフフォーカスの場合, MTF 值が 非常に低い值を示したのは，フィルムの粒状がぼけてし まっているために濃度データが平均化されて矩形波チャ 一ト像のコントラストが小さくなったためであると考光 られる.したがって, マイクロデンシトメータの対物レ ンズの焦点は，X線フィルムのどの面に合わせてもよい がピントが完全に外れた状態で測定してはならない.ス リット法による MTFでこの点を検討した論文としては 文献2)がある。

Fig. 5-3, Fig. 5-4 において長さ0.2 mm の MTF 值が 高くなったのは，濃度データの統計的ノイズが大きくな りコントラストを大きめに拾ったためであると考えられ る. Fig. 5-5 のように幅0.03 $\mathrm{mm}$ の場合は, 高さの差に よる変化はあまり見られなかったが全体に MTF 值が小 さくなっていた。これは，幅が広いために濃度データが 平均化された結果であると考える.

Fig. 5-6 はチャート像の細線とアパーチュアの高さ方 向の角度が大きくなるにつれて MTF 值は低下すること を示している．これは，特に高周波領域においてアパー チュアが細線像と交差した結果, チャート像の濃度のピ ーク值が小さくなるためであるといえる.したがって， チャート像の細線の長さ方向とアパーチュアの高さ方向 とは正確に平行にしなければならない.

Fig. 5-7 に示すように0.25 mm/sec でステージを移 動させた場合，マイクロデンシトメータのギアの組合わ せが大きく変わりステージを動かすモータの振動が大き くなった.そのため濃度データに振動ノイズが加わりコ ントラストを過大評洒したため MTF 值が高くなったと 考える. $0.5 \mathrm{~mm} / \mathrm{sec} の$ 場合も $0.1 \mathrm{~mm} / \mathrm{sec} に$ 比較する と，振動ノイズの影響を受けてはいたが, $0.25 \mathrm{~mm} / \mathrm{sec}$ のそれよりも小さかった。これは，測定を行うマイクロ デンシトメータ固有のものといえる. 施設によっては, $0.25 \mathrm{~mm} / \mathrm{sec}$ が一番静かに動くというところもあった. したがって，個々の機器特性を良く知った上で選ぶのが 良いといえよう。また，マイクロデンシトメータの設置 台を吸震・耐震特性のより良いものに交換することによ ってこれらの影響は小さくおさえることができると考え る.

\section{$5: 6$ 結 論}

矩形波チャート法による MTF の測定において，マイ クロデンシトメトリーの条件は次のようにすることを提 案する。

1）マイクロデンシトメータの対物レンズの焦点位置 は，X線フィルム上のどこに合わせてもよいが，どこに
合わせるかを施設内で決めておいて，それに統一した方 がよい.ただし，前面と後面を分けて考えなければなら ない非対称システムのような場合はこの限りではない.

2）アパーチュアサイズは, 幅 $0.02 \mathrm{~mm}$ 以下, 高さ0.5 $\mathrm{mm}$ 以上にして測定するのが望ましい。

3）サンプルチャート像の細線の長さ方向とアパーチ ユアの高さ方向は正しく平行にするべきである.

4）マイクロデンシトメータのステージ移動速度は 0.1 $\mathrm{mm} / \mathrm{sec}$ にするのがよい.ただし，これはマイクロデンシ トメータ固有の問題を含んでおり各施設でも確認した方 がよい. $\mathrm{A} / \mathrm{D}$ コンバータのサンプリング周波数は，ステ ージ速度に合わせて変化させる必要があることはいうま でもない.

これらの実験の中で経験的に知ったことは，マイクロ デンシトメータの濃度 0 調整を測定前に行うだけでなく, 测定後にも変動していないかを確認する必要があること である.一般的には，濃度測定はマイクロデンシトメー 夕の電源を入れて最低30分経過してから行うと比較的安 定したデータが得られるが，電源事情によっては，その 0 点が変動することがしばしばある。

(大阪中央病院 石田隆行)

\section{参考文献}

1）山下一也，段床嘉晴：画像部会報告，第 1 回画像り フレッシャースクール資料, 日放技学誌, $43(7), 787$ -794, (1987).

2）稲津 博, 他：X線フィルム濃度変動测定における 2,3 の問題点, 医用画像情報学会誌，8(3)，8694, (1991).

\section{第 6 章 チャート像の読み取り方法, SWRF の近似, 外挿およびコル トマンの補正式の計算次数に起 因する MTF の誤差の検討}

\section{1 はじめに}

チャート法によるMTF 測定において，作成されたチ ヤート像および特性曲線より MTFを算出する過程で, いくつか注意しなければならない問題点がある.この過 程でのエラーは最終 MTF 值に直接影響し，俁差を大き くするであろう。

ここでは MTF 算出時の誤差発生の要因となるチャー 卜像の読取方法, 矩形波レスポンス関数 (SWRF) の近 似, 外挿の問題, およびコルトマンの補正式について述 ベる. 